\title{
SCHOOL CLIMATE AND ORGANIZATIONAL CITIZENSHIP BEHAVIOR
}

\author{
Salome Ruguru Njagi (PhD) \\ Lecturer, University of Eastern Africa, Baraton \\ P.o Box 2500-30100, Eldoret, Kenya
}

\begin{abstract}
This study looks at some significant variables in Adventist schools in relation to organizational citizenship behavior $(O C B)$. The study is designed to address the problem, "To what extent does the school climate relate to the $O C B$ of the teachers?" The study seeks to provide a better theoretical understanding of OCB in Adventist schools in Kenya. One of the elements that enhance the performance of an organization is the OCB of its workers. Although OCB is important, little is known about the factors contributing to willingness of teachers going an extra mile in their workplace. The respondents were 170 teachers from Adventist schools in Kenya. The teachers responded to 2 instruments along with demographic variables. Thesewere the Organizational Climate Index and Organizational Citizenship Behavior Scale.
\end{abstract}

\section{KEYWORDS}

Organizational Citizenship Behavior, School Climate, professional teacher behavior, collegial leadership, achievement press and institutional vulnerability.

\section{INTRODUCTION}

One of the key elements that enhance the performance of an organization is the organizational citizenship behavior (OCB) of its workers. OCB is integral to the performance and effectiveness of organizations [27]. It is a call to go beyond the need of duty [24] and willingness to put in extra effort on the job. In educational institutions it is helping students and colleagues, and engaging in other beneficial school activities). OCB has proved to be an element that has a great impact on the success of organizations [2].There is a high turnover of teachers in most of the schools; even the commitment of the teachers that remain in these institutions is in question [22]. It is, therefore, important for the church to seek ways and means by which they can enable teachers to own their organization's mission. The individualistic trend in the world today tends to make the focus to be on what one can gain from associations, organizations and employment [24]. Usually work is done only as commensurate to the reward. With this trend there is a need to enlist workers to share and own their organization's mission. The ability of the workers to go beyond the call of duty is a need of many organizations [27]. This need is also in the field of education where willingness to go above and beyond the call of duty is necessary for the schools to attain their objectives and goals (Robbins, 2003).

One of the challenges of all school principals is to create a climate in which the teaching staff identify and affiliate with the institution and its mission. Therefore, school climate is the second 
International Journal of Education (IJE) Vol.6, No.1/2, June 2018

variable in this study. It is important to the entire organization. It describes the common perceptions of participants about regular behaviors, which eventually have an effect on their own behaviors as cited and attitudes in the institution [6]. OCB has a positive influence on the quality of the school climate. Research has shown that a positive climate in schools has many advantages. These include improved student performance, teachers' satisfaction in the participation of decision making in institutions, as well as school effectiveness [21].

The four dimensions of school climate are collegial leadership, professional teacher behavior, achievement press, and institutional vulnerability [16]. These dimensions have a positive influence on OCB [21]. For example, research has indicated that there is a positive influence when collegial leaders support teacher professionalism, thus OCB is enhanced [6]. Achievement press, an aim for academic accomplishment, is favorable for meeting organizational goals. There is a strong correlation between academic press and OCB[7]. In cases where there is low institutional vulnerability OCB is manifested [6]. Therefore a study on OCB in the context of educational institutions should investigate these correlations.

It is, therefore, important to see how certain aspects of school life result in progress or lack of OCB. It has been suggested that OCB is critical to performance of organizations [27]. How then can these qualities be achieved in Adventist schools Kenya? It is likely that one of the factors in a school setting that contribute to OCB is school climate. Though several research studies have explored factors related to $\mathrm{OCB}$, there seems to be a gap in theoretical considerations of whether the school climate of teachers working for a religious organization is related to their OCB towards that organization.

This study looks at some potential significant variables in Adventist schools in relation to OCB. The study is designed to address the problem, "To what extent is the teachers' perception of school climate relate to the OCB of the teachers?"

The goals of the study are to describe the concepts of school climate and OCB from the review of literature, to provide reliable and valuable data on school climate and OCB from Adventist schools in Kenya that will assist educators and school personnel to improve quality of teaching that will support the educational program and enhance commitment. Also to provide information so that a positive attitude may be developed among educators, administrators, and other stakeholders towards school climate and OCB of Adventist teachers in the Kenyan educational system.

This study will benefit the following groups of people: 1). Teachers in developing self-awareness about their OCB, and enhance their understanding of the level of school climate. 2). School administrators and principals/headmasters in understanding the school climate and OCB to facilitate better supervision and effective school practices. 3). Students in acquiring better learning environment through quality education and high achievement as teachers will develop self-awareness about their OCB in the school.

\section{LITERATURE REVIEW}

This section presents a review of literature on the major constructs of this study: school climate and relationship to OCB.OCB was introduced into academic literature through the works of Denis Organ [27]. It has grown in the last 3 decades to become a large field of research. Studies have 
International Journal of Education (IJE) Vol.6, No.1/2, June 2018

mainly focused on the corporate sector and studies on the relevance of OCB in schools are recent[6]. The studies on OCB in educational institutions have helped to show the relevance of OCB in schools. This study examines OCB among teachers in Adventist schools in Kenya.

Leaders in the educational sector should be cognizant of the value of OCB. Teachers play a significant role in the success of a school. Thus, the incidence of OCB in a school setting largely depends on their involvement. This section covers definition and elements of OCB that relate to teachers.

Any successful organization has workers who go an extra mile in their formal work responsibilities and give their energy and time for it to succeed [7]. Organ as cited in [27], states that OCB is an "individual behavior that is discretionary, not directly or explicitly recognized by the formal reward system and that in the aggregate promotes the effective functioning of the organization" (p. 150).

Later OCB was redefined as an influence that enhances performance [27]. It is a demonstration of a behavior that is out of free will, without any force. The employees go over their required duties in order to help their colleagues to achieve the goal of the organization. In essence, this is what OCB entails (Bass, 1990).

One of the key elements of OCB is the ability to do more than what is required for the interest of the organization. When employees perform beyond their normal duties they "develop a stronger conscientiousness about what they can do"p. 38 [29]. Consequently, the employees engage in healthy interpersonal relationships within the organization, do more than required, and forbear difficulties.

OCB is an extra role where an employee does not get any reward. "Reference[7]summarize the components of OCB as follows: 1). Altruism is when an employee demonstrates concern for the good of others without selfish motives. If a fellow worker is absent from work due to sickness or any reason, one can help him/her with the workload, and volunteer to teach their lessons. 2). Conscientiousness is true commitment when one stays up to late hours without taking extra breaks to finish what he/she has started. An employee obeys rules without being watched. 3). Civic virtue is when one meets all the organization appointments without being forced. A worker becomes aware of the changes in the organization and supports them. The teacher becomes responsibly involved in the political life of the school. 4). Sportsmanship is when an employee focuses on the positive aspects of an organization rather than the negative and wrong aspect of the organization. The employees listen to the advice of other members and share the joy of accomplishing a project together. 5). Courtesy is the act of showing empathy and understanding toward other workers without abusing their rights. They treat others with respect".

"Reference[6] describe the traits that indicate an employee who practices OCB is being cooperative, helpful, and caring. Workers must have job satisfaction and commitment before they engage in OCB". They must perceive that the organization in which they are working is supporting them and treating them with fairness.

Several studies concerning OCB have been done in the area of business, industries, and educational institutions. However, in the scope of this study, only the current relevant research on "Reference [27] observes that previous research on OCB found that organizational aspects 
such as commitment, satisfaction, and motivation mediated the employee OCB". The employees reciprocated the way the organization treated employees.

A high level of OCB is valuable to organizations. Tsai and Wu (2010) opine that OCB makes the workers to willingly engage in activities that enhance the performance of an organization. The study was conducted to find the reason for the high turnover of nurses in the health sector in Taiwan. This research aimed at finding ways of reducing employee turnover by enhancing OCB and job satisfaction. The findings showed that job satisfaction has a positive correlation with OCB.

"Reference [33]explore on OCB and organizational commitment explored how relationships are mentored in public school settings in Kansas City in the United States". The study comprised variables such as organizational commitment, workplace sense of community, and OCB. The outcome showed that there was a positive influence on the workplace sense of community and organizational commitment. Further, mentoring had a significant correlation with OCB.

A study on school climate has been done for many years and is ongoing. There is need for educational institutions to care about their school climate. The health of the teaching and learning environment is influenced by the school climate [11]. Previous studies have largely focused on the effect on student's academic achievement as attained through school climate. Yes, school climate has effect on students' accomplishment 16]. However, there is less information about school climate's influence on non-academic matters. This is one of the reasons that this study is undertaken.

A strong OCB needs a suitable environment to be nurtured. It does not develop in isolation in teachers' lives. These two realities, suitable environment and OCB, are closely related with each other. A combination of these two factors in an educational setting is an outcome of united interests and efforts.

The involvement of school leaders, parents, and students help in creating an appropriate environment that nurtures the daily interactions in an educational setting [23]. Reference [23]suggested that a devoted leadership could direct all the available influential aspects of school's climate, shaping them into potential avenues to express and to negotiate for opportunities that lead to moral motivations".

It is necessary to create an atmosphere that enables the growth of all the members of the school family [3]. In this sense, Christian institutions of education have an enormous pool of opportunities to improve the educational climate. The influence of the principal and the teachers become useful in making the atmosphere of the school in achieving its mission. The school environment can be changed when the principals share leadership. This can be done by sharing leadership in decision making and having good communication with teachers. There is a great opportunity for the principals to impact the lives and attitudes of teachers towards attaining the full potential of their efficiency regarding the changes needed in the climate of the school [4].

One of the dimensions of school climate is collegial leadership. "Reference [17] observe that collegial leadership creates a climate of citizenship". Collegial leadership is defined as the ability of the leader that is focused on attaining the social needs of the teachers and realizing the goals of the school. In this aspect of leadership the teachers are treated as professional colleagues by the principal. The principal deals with others openly, freely, and is friendly. Nonetheless, the 
International Journal of Education (IJE) Vol.6, No.1/2, June 2018

expectation and standards of performance are clearly set. Collegial leadership style of educational leaders has a strong link with OCB [17]. Furthermore, collegial leadership of the principal cultivates a climate that encourages OCB [7]. "Reference [17]further, found that when the principal demonstrates a higher level of collegial leadership what follows is the greater the amount of OCB in the faculty [17].

Another dimension of school climate is teacher professionalism. It has a correlation with OCB [7]. The manifestations of teacher professionalism are high esteem for co-workers, capability, and dedication to students, independent judgment, reciprocal collaboration, and support. These factors by and large influence school climate. The confidence aspect of teacher professionalism generates interest, belief, and a sense of achievement. Nevertheless, the main goal is in the achievement of the student [18]. One of the key aspects in promoting teacher professionalism in schools is OCB. It is unimaginable for professionalism in teachers to develop without OCB [7]. This is important in evaluating the role of OCB in the target schools as undertaken in this study.

Achievement press is the third dimension of school climate. It is closely linked to OCB. Academic excellence in a school is mainly promoted by organizational citizenship [7]. Achievement press is an educational endeavor of setting high but achievable academic standards and goals. In a school where the energy and efforts are focused on attaining the professional goals there is a strong academic press. A strong achievement press describes a situation where all

principal, teachers, parents, and students aspire for academic excellence. Such an aim is achievable in circumstances where those involved are willing to go an extra mile. There is, therefore, a strong relationship between academic press and OCB. "Reference [5] refer to achievement pressas the extent to which the school community, students, teachers, administrators, and parents are driven by a quest for academic excellence [6]. Teachers and administrators in such schools set a tone that is serious, orderly, and focused on academics. (p. 257)

The fourth aspect of school climate, institutional vulnerability, correlates with OCB to some degree. The school life is affected by both high and low vulnerability [6]. When the school is not susceptible to too much of community pressure then it results a low vulnerability. On the other hand, when the teachers and the principal are unprotected and on the defensive from external forces then there is high vulnerability. Teachers work well in an environment of low vulnerability. In such an environment they put forth their best efforts to accomplish the goals of the institutions[7].

Studies through the centuries have indicated that school climate is a factor that improves the teachers' productivity and eventually enhances the performance of the students. "Reference [18]says that the school principals should take note of the significance of the relationship between OCB in the setting of the organization and school climate". There is a likelihood of teachers showing better citizenship in their job with colleagues as well as helping their students in organizations with open healthy climates. .

\section{RESEARCH METHODOLOGY}

This study is cross-sectional survey design using descriptive and correlational statistics. The study is descriptive because it seeks to determine the school climate and OCB in the schools of CKC. The nature of descriptive design is to describe the respondents' perception by calculating frequency distributions, means, and standard deviations of their perceptions while considering 
International Journal of Education (IJE) Vol.6, No.1/2, June 2018

demographic variables, such as age, gender, marital status, highest education completed, and number of years teaching in the school for defining relationship of difference and association. The descriptive methods investigate and gather information about this study and explore and analyze the data [9].

This study is correlational because it seeks to determine the perceptions of teachers about school climate, and the frequency with which a teacher demonstrates effective OCB in Adventist schools in Kenya. Correlational procedures allow researchers to make inferences about relationships between two or more variables [6]. It further analyzes data to determine the predictors of OCB.

The target sample of this study includes all teachers in Adventist schools that are under the Education Department of CKC. All the teachers in the CKC who met the following requirements may participate:1).They are full-time and part-time employees of the current school. 2).They provide consent to participate in the study.3).They are available during data collection time, since the study includes the total population, sampling procedures is not necessary. All the teachers qualify to take part as long as they meet the set criteria above.

The study used two survey instruments: (1) OCI [16]; and (2) OCBS[7]. Relevant demographic variables (age, gender, marital status, educational degree completed, and years of teaching in the school) are included to allow data to be categorized and studied in the analysis. Permission was granted by the authors for using all the instruments.

\section{FINDINGS}

The main purpose of this study was to provide insights into the relationships between school climate and $\mathrm{OCB}$ in $\mathrm{CKC}$ schools. There were several essential objectives tied to the major purpose of this study: (1) to determine if there were any relationships between perception on the school climate profile and OCB; (2) to determine if certain teacher demographic variables relate to their perception of school climate profile and OCB; and (3) to find the best predictive model for OCB considering variable such as perception of school climate profile.

\subsection{Differences in perception on school climate variables by demographic}

Is there any difference in school climate dimensions based on demographic variables? The demographic variables are age, gender, marital status, education degree, and years of teaching in the school. A one way-ANOVA test was performed. The ANOVA result showed that groups formed on age, years of teaching experience, and highest degree had significant differences.

School climate variables and gender. One-way ANOVA test was conducted to determine if there is a difference in school climate when grouped by gender. Results showed that there is no statistically significant difference in perception of collegial leadership, achievement press, professional teacher behavior, and institutional vulnerability between male and female teachers.

School climate variables and marital status. One-way ANOVA test was performed to determine if there is a difference in perception of teachers' collegial leadership, achievement press, professional teacher behavior, institutional vulnerability when grouped by marital status. Results indicated that there was no significant difference between married and single teachers. 
School climate variables and age. One-way ANOVA was used to test the null hypothesis that stated "there is no significant difference in perception between age below 30 years, 30-49 years, and 50 years and above on the school climate variables." Results revealed that there is no significant statistical difference.

There was no significant difference in perception between age categories of the respondents and collegial leadership, achievement press and institutional vulnerability in the school (see Table 10). However, for the perception on professional teacher behavior the results showed that there is a significant difference, $F(2,147)=5.233, p=.006$, between below 30 years $(M=3.24, S D=$ $.60), 30-49$ years $(M=2.97, S D=.49)$, and 50 years and above $(M=3.33, S D=.47)$. Further, post hoc analysis showed a difference significant, $F(2,147)=5.233, p=.012$, between below 30 years $(M=3.24, S D=.60)$, and 30-49 years $(M=2.97, S D=.49)$, between teachers who are below 30 years and professional teacher behavior.

School climate variables and number of years teaching in the school. One-way ANOVA was used to test the null hypothesis. The hypothesis stated, "There is no significant difference of teachers' perception on organizational citizenship when grouped by years of teaching experience of the respondents." The years of teaching were categorized into four groups as follows: less than a year, between 1 and 3 years, between 3 and 5 years, and more than 5 years. Results indicated that there is no statistically significant difference in the number of years teaching in the school and perception on teacher's achievement press and institutional vulnerability in the school.

However, for collegial leadership in the school results indicated that there is a significant difference, $F(3,146)=3.301, p=.022$, between less than 1 year $(M=3.03, S D=.68), 1$ to 3 years $(M=2.84, S D=.82), 3$ to 5 years $(M=2.82, S D=.81)$, and over 5 years $(M=2.47, S D=.83)$. Further, post hoc analysis showed a significant difference, $F(3,146)=3.301, p=.018$ between less than 1 year $(M=3.03, S D=.68)$ and over 5 years $(M=2.47, S D=.83)$, between teachers who have been teaching for less than one year and collegial leadership in the school. Results revealed that there is a significant difference, $F(3,146)=3.080, p=.029$, between less than 1 year $(M$ $=3.36, S D=.51), 1$ to 3 years $(M=3.11, S D=.49) 3$ to 5 years $(M=3.13, S D=.60)$ and over 5 years $(M=2.96, S D=.58)$, in perception on professional teacher behavior. Further, post hoc analysis showed a significant difference, $F(3,146)=3.301, p=.015$ between less than 1 year $(M$ $=3.03, S D=.68)$ and over 5 years $(M=2.47, S D=.83)$, between teachers who have been teaching for less than one year and professional teacher behavior in the school.

Therefore in the number of years teaching in a school, the respondents significantly differed in their perceptions. The perceptions on collegial leadership and professional teacher behavior significantly differed between those with less than one year and those with more years.

School climate variables and highest education completed. One-way ANOVA was used to test the null hypothesis that stated, "There is no significant difference between teachers' perception on school climate when grouped by educational degree of the respondents." The educational degree was categorized into three groups as follows: below bachelor's, bachelor's, and master's. For the two variables, professional teacher behavior and institutional vulnerability in the school the results showed that there is no statistically significant difference.

The null hypothesis was rejected for two variables. Results indicated that there was a significant difference, $F(2,147)=4.797, p=.010$, between below bachelor's degree $(M=2.95, S D=.77)$, bachelor's degree $(M=2.55, S D=.81)$ and master's $(M=3.00, S D=.87)$. Further, post hoc 
International Journal of Education (IJE) Vol.6, No.1/2, June 2018

analysis showed a significant difference, $F(2,147)=4.797, p=.015$, between below bachelor's degree $(M=2.95, S D=.77)$ and bachelor's degree $(M=2.55, S D=.81)$, in perception on collegial leadership. There was a significant difference, $F(2,147)=10.319, p=.000$, between below bachelor's degree $(M=3.18, S D=.54)$, bachelor's degree.

$(M=2.82, S D=.50)$, and master's $(M=3.45, S D=.52)$, in perception on achievement press. Further, post hoc analysis showed a significant difference, $F(2,147)=10.319, p=.000$ between below bachelor's degree $(M=3.18, S D=.54)$, bachelor's degree and $(M=2.82, S D=.50)$, in perception on achievement press (see Table 1). Further analysis on the basis of different school climate variables revealed that respondents significantly differed by their demographic variables in their perceptions on collegial leadership and achievement press.

\subsection{Differences in perception on organizational citizenship behavior by demographic.}

Is there any differences on OCB by demographic variables? The demographic variables are age gender, marital status, education degree, and years of teaching experience. A one way-ANOVA test was performed. The ANOVA result showed that only groups formed on age and highest degree had significant differences. Further, post hoc test was performed for age, and highest degree and it identified the categories that are significantly different.

Organizational citizenship behavior and gender.The ANOVA was conducted to determine if there is a difference in OCB when grouped by gender. Results showed that there is no significant difference in perception between male and female teachers on OCB

Organizational citizenship behavior and marital status. ANOVA test was performed to determine if there is a difference in OCB when grouped by marital status. Results indicated that there was no significant difference in perception between married and single teachers on OCB.

Organizational citizenship behavior and age. One-way ANOVA was used to test null hypothesis that stated, "There is no significant difference of teachers' perception on OCB between the age categories of the respondents." Age was categorized into three groups as follows: below 30 years, $30-49$ years, and 50 years and over. The null hypothesis was rejected. The results showed that there was significant difference, $F(2,147)=3.533, p=.032$, between below 30 years $(M=4.26, S D=.64), 30-49$ years $(M=4.01, S D=.57)$ and above 50 years $(M=4.31, S D=.59)$, in perception on OCB. Further, using the post hoc analysis significant difference, $F(2,147)=$ $3.533, p=.040$, below 30 years $(M=4.26, S D=.64)$, and30-49 years $(M=4.01, S D=.57)$, in perception on OCB. "Reference[26] had the similar finding that young teachers demonstrate higher levels of OCB more than the older colleagues".

Organizational citizenship behavior and number of years teaching in the school. One-way ANOVA was performed to determine if there is a difference in OCB when grouped by years of teaching experience. The teaching experience was categorized into four groups: less than a year, between 1 and 3 years, between 3 and 5 years, and more than 5 years. Results indicated that there was no statistically significant difference in perception of teachers between years of teaching experience and OCB . 
International Journal of Education (IJE) Vol.6, No.1/2, June 2018

Organizational citizenship behavior and highest educational completed. One-way ANOVA was used to test if there is a difference in OCB when grouped by educational degree of the respondents. The educational degree was categorized into three groups: below bachelor's degree, master's degree, and doctorate degree. Results indicated that there was a significant difference, $F(2,147)=5.388, p=.006$, between below bachelor's $(M=4.27, S D=.63)$, bachelor's $(M=$ $3.97, S D=.55)$, and master's $(M=4.50, S D=.67)$, in perception on OCB.

Further, post hoc result indicated a significant difference, $F(2,147)=5.388, p=.009$, below bachelor's $(M=4.27, S D=.63)$ and bachelor's $(M=3.97, S D=.55)$, in perception on OCB. The mean is higher for teachers without bachelor's degree compared to those with bachelor's degree. Research suggests that teachers are more satisfied if their job provides opportunities for personal and professional advancement, has an enormous system of teacher in-service training, and there are many opportunities for teachers to continue their education [6].Such opportunities can increase the morale of teachers who have a diploma and strive hard to achieve and be willing to go an extra mile [32]. Diploma teachers are still growing in their career. They work hard to strive for the best since they want to succeed in their careers. Other studies have indicated that educational level have no significant effect on OCB at the school level [6].

School climate can affect individuals in the school in any various ways Hoy [6] discovered that school climate has a correlation with the performance of the teachers. Thus, it could be hypothesized that in a school where collegial leadership and teacher professional behavior is practiced, and has strong achievement press and low institutional vulnerability, performance increases. Studies have shown that collegial leadership, teacher professional behavior, strong achievement press and low institutional vulnerability can cultivate a climate that encourages OCB ([6];[19]; [21]).

\subsection{Predictive Model for Organizational Citizenship Behavior}

In this study 150 teachers were the respondents, out of which $55.3 \%$ were male and 44.7 were female. Considering the school climate dimensions, professional teacher behavior had the highest mean, while institutional vulnerability had the lowest mean score..

Table 1 Summary: Best Predictive Model for Organizational Citizenship Behavior Model $R R^{2}$ Adjusted $R^{2}$ change $F$ change $d f 1$ df 2 Sig. $R^{2} F$ change

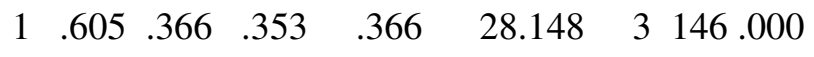

Note. $p<.05$.

Teachers' OCB predictors were professional teacher behavior and achievement press. Among these professional teacher behavior had the strongest association with teachers' OCB $(\beta=.300)$. Thus, it is the best predictor of teacher OCB as perceived by teachers in CKC schools.

Among the school climate dimensions, professional teacher behavior $(M=3.15)$ indicated the highest mean, followed by achievement press and collegial leadership. Teachers below 30 years perceived professional teacher behavior to have a positive outcome in the school. Teachers with no bachelor's degree perceived collegial leadership and achievement press to have an influence in 
International Journal of Education (IJE) Vol.6, No.1/2, June 2018

their school while those who had been teaching for less than one year in their school, perceived collegial leadership and professional teacher behavior as being practiced in the school.

Teachers have an influence in the teaching profession. Young teachers are positively related to professional teacher behavior in schools. Schools are service oriented. Thus, the teachers' main focus is on the students in discovering effective methods of instruction through collaboration with other teachers [7]. Young teachers indicate a higher level of commitment in their professionalism ultimately leading to success in their teaching career [1]. Studies have supported the idea that teachers in Adventist schools were from a younger age group resulting in better performance in schools [20]. "Reference [13] on the contrary, states there are trends of increased performance by older teachers in the Adventist schools.

On the number of years of teaching in a school, studies have shown that teachers become more effective during the first few years of their career. "Reference [28] observed a trend for the teachers with less years of experience to report positive school climate than the ones who have been teaching for a longer time". This was because of intimacy and support by the leader.

There is a trend for the teachers with less seniority to report higher favorable climate than the ones with moreseniority in relation to the factor of organizational support [14]. Professionalism has an impact on the teaching process. Teachers who have taught for fewer years in their school demonstrate a higher level of professional teacher behavior. In fact, young professionals, studies show, impart support to others to succeed [7].

The purpose of teaching is to have professionals who are independent in demonstrating their commitment to students, teachers who have few years in teaching in their schools seemed to have the urge and energy to influence others [25]. "Reference [12] however, had contrary result and found teachers who had more years in their teaching experience had a positive view of performance in their school".

Teachers' education level makes a difference in one's career. In this study teachers with no bachelor's degree have a higher perception on collegial leadership and achievement press. Schools with collegial leaders who encourage high achievement press have teachers who go beyond the minimal requirements to help and encourage students toward excellence. Teachers with lower level of education in schools volunteer to go out of their way to help their colleagues and others $\{6]$. This may be because they are still growing in their careers and they have not had a fixed opinion about issues and they are driven by quest for academic excellence and still aiming high for success [35]. Since diploma qualification serves as a foundation for increasing amount of education in their career they aspire to achieve both personal and career goals in life. On the contrary, Reyes [30] states that teachers who have attained higher degrees perform better in teaching than those with lower educational degree.

Theory support that among school climate dimensions, professional teacher behavior, achievement press, and collegial leadership do have a positive influence on the performance of teachers in school [7]. Prior studies showed that perceived professional teacher behavior, collegial leadership, and achievement press when demonstrated by teachers do have an impact on school and members of the school community ultimately improving performance in the school [6].

In any institution teachers look to leaders for guidance and directions and their view is to aim high for the institution to succeed. "Reference[21] found that collegial leadership had positive 
International Journal of Education (IJE) Vol.6, No.1/2, June 2018

effect on OCB. Collegial leadership of the principal was highly related with OCB, the greater the degree of collegial leadership, the stronger the degree of OCB in schools. Collegial leadership of the principal is when the principal is viewed to have friendly and approachable attributes. High achieving schools tend to have leaders who allow teachers to take part in the leadership roles, through collaboration. In a school where teacher collaboration is practiced there is mutual learning [6]. An effective collegial leader informs the teachers what they are expected to do and also incorporates suggestions made by the teachers.

Teachers indicated OCB as being practiced at CKC schools. Teachers who are below 30 years and do not have bachelor's degree tend to have a positive view on OCB. In a school setting where young teachers collaborate and get support from other teachers, they are more satisfied and willing to go beyond their duties. They are also willing to accommodate new ideas and mentoring programs which help them to adjust easily [32]."Reference [10] showed that teachers exhibit higher levels of OCB, since they want to make their institution succeed". On the contrary, other studies found a negative effect between age and highest education completed and OCB ([8]; [26]).

Findings of the present study show that the best predictive model of OCB was made up of professional teacher behavior and achievement press as predictors of OCB (see Figure below).These three variables together accounted for $35.3 \%$ of the variance in teachers' OCB. Among these professional teacher behavior $(\beta=.300)$ was the best predictor followed by achievement press $(\beta=.272$. This finding seems to indicate that schools where professional teacher behavior and achievement press are extensively practiced may be ideal for promoting teachers' OCB. Professional teacher behavior indicates strength in teaching and demonstrates the strength of one's knowledge in a particular area. The main reason for teaching is for teachers to go beyond minimal requirements specified in the classroom tasks [17]. It also extends to the demonstration of self-direction focused on their understanding and commitment to students, since they are devoted to the success of their student [17].

$$
\mathrm{R} 2=35.3 \%
$$

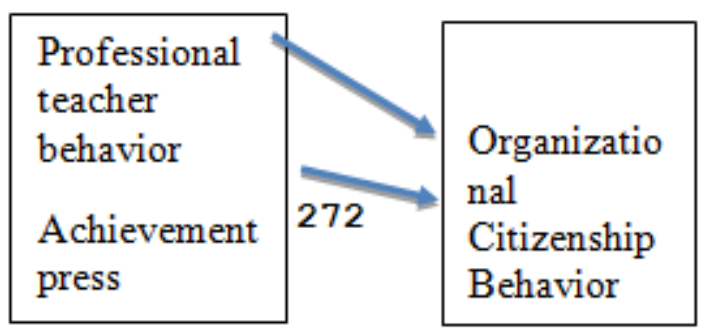

Figure 1 Best predictive model for organizational citizenship behavior.

Therefore, teacher professionalism is going beyond one's responsibility. Achievement press is the degree to which the school looks at the teachers and leaders to strive for academic and achievement of students [16]. In institutions that indicate high achievement press, teachers go beyond the minimal requirement to help and motivate students toward excellence. Teachers in these schools freely go out of their way to assist learners, fellow teachers and others as they do their work of teaching and learning [25]. As a result learners respond by appreciating academic excellence and valuing academic accomplishment of their peers[6]. 
International Journal of Education (IJE) Vol.6, No.1/2, June 2018

Schools are service organizations where the focus is on helping students. Teachers work mostly alone in the classroom in guiding and providing the knowledge and skills and finding the best ways of delivering the information [7].It is also helpful to seek help and support from fellow teachers to enhance effective school climate. Therefore, for any school to succeed, professional teacher behavior and academic press must be emphasized and supported. This study found a positive relationship between professional teacher behavior and achievement press which increases teachers' OCB.

\section{CONCLUSIONS}

The following conclusions are drawn on the basis of the result of the study concerning the constructs of school climate, and their organizational citizenship behavior:

1. Majority of CKC teachers are married and have no bachelor's degree and are males.

2. Teachers with lower than bachelor's degree education, below 30 years of age, and have been teaching for less than one year in the school were significantly different than other categories, on OCB and school climate scales-professional teacher behavior, collegial leadership, and achievement press.

3. The instruments utilized in the study (OCI and $\mathrm{OCB}$ ) were adequate for utilization in Adventist schools in Kenya.

4. Of the school climate scales, professional teacher behavior and achievement press were the two better predictors of OCB, since teachers having lower than bachelor's degree education and below 30 years of age differed significantly with other categories of respective demographic variables on professional teacher behavior, achievement press, and OCB. It appears that in the predictive model these categories of teachers seem to have played a significant role.

5. This study will help teachers to develop self-awareness about their OCB, which will increase commitment that will show in the character of the students through Christ like behavior.

6. This study will equip the school administrators in understanding their own school climate and $\mathrm{OCB}$, and further it will help them to understand and help teachers to get more involved in OCB activities.

\section{RECOMMENDATIONS}

This study provides various recommendations for practice and further research. These include recommendations which are primarily targeted at administrators of Adventist schools, as well as for further research.

\subsection{Recommendations for Educational Practice}

Teachers are crucial elements in the educational process[6]. Therefore, leaders are encouraged to nurture OCB in the schools. There are yet several things leaders can do to encourage the teachers' willingness to go an extra mile. To achieve the mission of a Christian's higher calling more 
International Journal of Education (IJE) Vol.6, No.1/2, June 2018

effectively through teachers going an extra mile, it is recommended that leaders should, Ensure that professional teacher behavior and achievement press are cultivated in the school for teachers to develop OCB, through fostering a caring community, as they are good predictors of OCB.

\subsection{Recommendations for Future Research}

Several recommendations for future research were made based on the results of this study, which are as follows:

1. Triangular techniques could be utilized to further probe into the OCB. A qualitative procedure might help in the endeavor. Further, since this study sample included only teachers, subsequent studies might include principals and students to get their perception on the variables of this study as well.

2. Replicate this study in other geographical regions and cultures to strengthen the generalizability of this study's findings.

3. Since the study was done in Adventist schools, a related study might be conducted to check whether there are significant differences in the factors contributing to the teachers' OCB between religious institutions and non-religious institutions.

4. Although the nature of this study was primarily quantitative, future studies might wish to combine quantitative and qualitative methods of research. Qualitative part may help find out why teachers with higher education and in the higher age bracket were not as involved in professional teacher behavior, achievement press and OCB.

\section{REFERENCES}

[1] Arnold, M. S. (1981). Economic and attitudinal corollaries of settlement behavior ineducational negotiations in Pennsylvania. The Pennsylvania State University. Retrieved from http://www.aiias.edu: $2057 /$ pqdweb $?$ index $=0 \&$ did $=753120941 \&$ SrchMode $=1 \&$ sid $=1 \&$ Fmt $=2 \&$ VInst $=$ PROD\&VType $=P Q D \& R Q T=309 \&$ VName $=P Q D \& T S=1320250825 \&$ clientId $=55185$

[2] Bogler, R., \& Somech, A. (2005). Organizational citizenship behavior in school: How does it relate to participation in decision making? Journal of Educational Administration, 43(5), 420-438. doi:10.1108/09578230510615215

[3] Caudron, S. (1995). Create an empowering environment. Personnel Journal, 74(9), 28-36.

[4] Chen, M., \& Addi, A. (1996). Educational leaders' influence on teachers and schools. Curriculum and teaching, 11 (1), 69-77.

[5] Creswell, J. W. (2005). Educational research: Planning, conducting, and evaluating quantitative and qualitative research (5th ed.). Upper Saddle River, NJ:Pearson Education.

[6] DiPaola, M. F., \& Hoy, H. K. (2005). School characteristics that foster organizational citizenship behavior. In W. Hoy, \& M. DiPaola (Eds.), Essential ideas for the reform of American schools (pp. 251-271). Charlotte, NC: Information Age. 
International Journal of Education (IJE) Vol.6, No.1/2, June 2018

[7] DiPaola, M. F., Tarter, C. J., \& Hoy, W. K. (2007). Measuring organizational citizenship of schools: The OCB scale. In W. Hoy, \& M. DiPaola (Eds.), Essential ideas for the reform of American schools (pp. 227-250). Charlotte, NC: Information Age.

[8] Denholm, P. J. (2002). A study of OCB and trust in a public high school.(EdD dissertation). The college of Wilmington, Delaware.Retrieved from http://www.aiias.edu:2057/pqdweb?index $=0 \&$ $\mathrm{did}=726130871 \&$ SrchMode $=1 \& \operatorname{sid}=4 \&$ Fmt=2\&VInst=PROD\&VType=PQD\&RQT=309\&VName= PQD\&TS=1321802886\&clientId=55185

[9] Fraenkel, J. R., \& Wallen, N. E. (2006). How to design and evaluate research in education (6thEd.). New York, NY: McGraw-Hill Irwin.

[10] Garg, P., \& Rastogi, R. (2006). Climate profile and Organizational citizenship behavior ofteachers in public and private schools of India. The International Journal of educational Management,20(7), 529541. Retrieved from http://www.emeraldinsight.com/journals.htm?articleid=1572864

[11] Glasser, W. (1998). The quality school: Managing students without coercion (2nd ed.). New York, NY: HarperCollins.

[12] Green, J. D. (2011). Factors related to special education teacher job commitment: A study of one large metropolitan school district in Southern California Pepperdine University. Retrieved from http://www.aiias.edu:2057/pqdweb?index=0\&did=2314791831\&SrchMode=1\&sid=6\&Fmt=2\&VInst $=$ PROD $\&$ VType $=$ PQD $\&$ RQT $=309 \& V$ Name $=$ PQD $\& T S=1318777840 \&$ clientId $=55185$

[13] Gude, K. (2009). Secondary school beginning teachers' perceptions of efficacy, school culture and professional commitment in Ethiopia. (Unpublished doctoral dissertation). Adventist International Institute of Advanced Studies, Silang, Cavite, Philippines.

[14] Gunbayi, I. (2007). School climate and teachers' perceptionson climate factors: Research into nine urban high schools. Retrieved from http://www.tojet.net/articles/637.pdf

[15] Ham, S. (2011). A Collegiality as uncertainty management: Multilevel contexts of collaborative teacher interactions. Michigan State University. Retrieved from

http://gradworks.umi.com/34/53/3453110.html

[16] Hoy, W. K. (n.d.). Organizational climate index (OCI). Retrieved from http://www.waynekhoy.com/oci.html

[17] Hoy, W. K., \& Miskel, C. G. (2005). Educational administration: Theory, research, and practice. Boston, MA: McGraw Hill Irwin.

[18] Hoy, W. K., \& Tschannen-Moran, M. (2007). The conceptualization and measurement of faculty trust in schools: The omnibus t-scale. In W. Hoy, \& M. DiPaola (Eds.), Essential ideas for the reform of American schools (pp. 87-114). Charlotte, NC: Information Age.

[19] Jahad, F. F. (1995). A descriptive examination of teachers' perceived job satisfaction and organizational citizenship behaviors across four leadership style of principals. (EdD dissertation). North Carolina State University. Retrieved from http://www.aiias.edu:2057/pqdweb?index=0\& $\mathrm{did}=742054191 \&$ SrchMode $=1 \&$ sid $=3 \& \mathrm{Fmt}=2 \& \mathrm{VInst}=\mathrm{PROD} \& \mathrm{VType}=\mathrm{PQD} \& \mathrm{RQT}=309 \& \mathrm{VName}=$ PQD\&TS=1318169671\&clientId=55185 
International Journal of Education (IJE) Vol.6, No.1/2, June 2018

[20] John, M. C. (1998). Relationship of leadership style, school climate, and the organizational commitment of teachers in the Seventh-day Adventist Secondary Schools in the Philippines. (Unpublished doctoral dissertation). Adventist International Institute of Advanced Studies, Silang, Cavite, Philippines

[21] Jurewicz, M. M. (2004). Organizational citizenship behavior of middle school teachers: A study of their relationship to school climate and student achievement. (EdD dissertation). The College of William and Mary. Retrieved from http://www.aiias.edu:2057/pqdweb?index $=0 \& d i d=765351611 \&$ SrchMode=1\&sid=5\&Fmt=2\&VInst=PROD\&VType=PQD\&RQT=309\&VName=PQD\&TS=131809 $8736 \&$ clientId $=55185$

[22] Kamundi, S. (2008). Adventist education, center for evangelism. In proceeding of the East Central Africa Division teachers' convention. Baraton, Kenya.

[23] Knight, M. E., Graham, T. L., Juliano, R., Miksza, S. R., \& Tonnies, P. G. (1982).Teaching children to love themselves: A handbook for parents and teachers of young children. Englewood Cliffs, NJ: Prentice-Hall.

[24] Kreitner, R., \& Kinicki, A. (2004). Organizational behavior. Boston, MA: McGraw-Hill Irwin.

[25] Kulleseid, E. R. (1982). A study of survival: three New York city elementary school library media centers and their support components. Columbia University.Retrieved from http://www.aiias.edu:2057/pqdweb?index $=2 \&$ did=753159221\&SrchMode $=1 \&$ sid $=1 \&$ Fmt $=2 \&$ VInst $=$ PROD\&VType $=$ PQD\&RQT $=309 \& V N a m e=P Q D \& T S=1320255334 \&$ clientId $=55185$

[26] Kuskova, V. V. (2010). An empirical examination of the relationship between life satisfaction and employee volunteerism: A longitudinal analysis. Indiana University. Retrieved from http://www.aiias.edu:2057/pqdweb?index $=0 \&$ did=2171996631\&SrchMode $=1 \&$ sid $=1 \&$ Fmt $=2 \&$ VInst $=$ PROD\&VType $=$ PQD\&RQT=309\&VName=PQD\&TS=1318794254\&clientId=55185

[27] Luthans, F. (2008). Organizational Behavior. Boston, MA: McGraw Hill Irwin.

[28] Mattingly, J. W. (2007). A study of relationships of school climate, school culture, teacher efficacy,collective efficacy, teacher job satisfaction and intent to turnover in the context of year-round education calendars. (PhD dissertation). University of Louisville. Retrieved from:

2057/pqdweb?index=0\&did=1425301731\&SrchMode=1\&sid=1\&Fmt=2\&VInst=PROD \&VType=PQ D\&RQT=309 \&VName=PQD\&TS=1322122669\&clientId=55185

[29] McShane, S. L., \& Von Glinow, M. A. (2008). Organizational behavior. Emerging realities for the workplace revolution. Boston, MA: McGraw Hill Irwin.

[30] Reyes, F. C. (2002). Unveiling teaching expertise: A showcase of sixty-nine outstanding teachers in the Philippines. Manila, PI: De La Salle University Press.

[31] Robbins, P. S. (2003). Organizational behavior (10th ed.). Upper Saddle River, NJ:Prentice Hall.

[32] Sargent, T. \& Hannum, E. (2003). Keeping Teachers Happy:Job Satisfaction among Primary School teachers in Rural Northwest China. University of Pennsylvania. Retrieved from http://www.ssc.upenn.edu/china/gscf/documents/sargent_hannum.PDF 
International Journal of Education (IJE) Vol.6, No.1/2, June 2018

[33] Schrum, J. L. (2002). The influence of formal mentoring relationships on organizational commitment, citizenship behaviors, and workplace sense of community in school settings.( $\mathrm{PhD}$ dissertation). University of Missouri-Kansas City. Retrieved from

http://www.aiias.edu:2057/pqdweb?index $=9 \&$ did $=765052951 \&$ SrchMode $=1 \&$ sid $=29 \& F m t=2 \&$ VInst $=\mathrm{PROD} \& \mathrm{VType}=\mathrm{PQD} \& \mathrm{RQT}=309 \& \mathrm{VName}=\mathrm{PQD} \& \mathrm{TS}=1318174170 \&$ clientId $=55185$

[34] Schulman, J. (2002). The effects of leadership style and school climate on student achievement. (EdD dissertation). Fordham University. Retrieved from http://www.aiias.edu:2057/pqdweb?index $=0 \&$ did $=727396961 \&$ SrchMode $=1 \&$ sid $=32 \&$ Fmt $=2 \&$ VInst $=$ PROD\&VType $=$ PQD \&RQT=309\&VName=PQD \&TS=1318174714\&clientId $=55185$

[35] Sennun, S., (2002).The relationship between change facilitator style of secondary school principals and school climate as perceived by teachers in the Church of Christ schools in Thailand. $(\mathrm{PhD}$ dissertation). Illinois State University. Retrieved from

http://www.aiias.edu: $2057 /$ pqdweb $?$ index $=0 \&$ did $=765625981 \&$ SrchMode $=1 \&$ sid $=33 \&$ Fmt $=2 \&$ VInst $=\mathrm{PROD} \& \mathrm{VType}=\mathrm{PQD} \& \mathrm{RQT}=309 \& \mathrm{VName}=\mathrm{PQD} \& \mathrm{TS}=1318174817 \&$ clientId $=55185$

[36] Tsai, Y., \&Wu, S. (2010). The relationships between organizational citizenship behavior, job satisfaction and turnover intention. Journal of Clinical Nursing,19 (23-24), 3564-3574.

doi:10.1111/j.1365-2702.2010.03375.x 